\title{
Education for Sustainable Development in the Value System of Teachers
}

\author{
By Tetyana Galtseva ${ }^{1}$, Svitlana Svitich ${ }^{2}$, Andriy Kutsiy ${ }^{3}$, Victoria Savchenko ${ }^{4}$, \\ Tetyana Strukova ${ }^{5}$
}

\begin{abstract}
Education for sustainable development shows all the necessary from sustainable development concept in unity of ecologic, social-cultural, and economic spheres. The reduction of education for sustainable development to the issue of environmental education poses a threat to the values associated with the humanistic interpretation of education. Firstly, it is the absolutization of environmental values and the lack of effective synthesis of these values with social values, and economic values partly. Secondly, there is a lack of needs and values of teachers and valuemethodological principles of integration of environmental and humanistic values. Thirdly, to a large extent on the periphery of education for sustainable development are the problems of transformation of society itself, social relations, culture, ways of communication, interaction of people with each other, as well as the emotional component of such interaction. One of the possible ways to solve these problems can be considered the formation of new, more adapted to the needs of sustainable development of value-cognitive characteristics of teachers. The new model of education should provide a focus on people as the main object of sustainable development, subordinating value changes to the task of socialization and humanization of social development, taking into account environmental constraints. Based on the results of the study, it is necessary to pay attention to the development of social intelligence, emotional intelligence, communicative intelligence and practical intelligence. For more adequate training of professionals in the field of education for sustainable development, it is advisable to expand cooperation with governmental and nongovernmental organizations.
\end{abstract}

Key words: education, sustainable development, humanism, ecology, training, values, social intelligence.

\section{Introduction}

Education for sustainable development is an important instrument for formation of values and knowledge about society that is in a state of balanced harmony with nature and provides balance between human's needs and its cooperation with environment. Education for sustainable development already has quite big history and, as a result, its principles, targets, mechanisms of realization were depicted in many

| ${ }^{1}$ Doctor of Psychology, Head of the Department of Psychology in Dnipro Academy of Continuing Education. Ukraine

${ }^{2} \mathrm{PhD}$, Prof. Asoc., Department of the Education and Culture of Health in Dnipro Academy of Continuing Education. Ukraine

3PhD, Prof. Asoc., Department of the Education and Culture of Health in Dnipro Academy of Continuing Education. Ukraine

${ }^{4} \mathrm{PhD}$, Prof. Asoc., Department of the Education and Culture of Health in Dnipro Academy of Continuing Education. Ukraine

${ }^{5}$ Strukova Tatiana, methodologist, educational and methodical laboratory of quality assurance of education in Dnipro Academy of Continuing Education. Ukraine 
international documents, national development programs, and several educational projects. The contents of the concept of sustainable development lie in necessity of conserving of available potential of our planet for future generations with the help of radical decrease of anthropogenic pressure on environment, which can be obtained with the help of drastic changes in society's life, its values and development targets.

\section{Literature Review}

This term was founded in 1992 at UN Conference of Environment and Development in Rio-de-Janeiro. "Agenda 21" has defined global task as a "mutual agreement of economical, ecological, and social development factors" [Agenda 21, 1992]. At World Sustainable Development Summit in 2002 basic vectors of sustainable development were defined (crystallization of the problem; partnership and responsibility; organized common actions; value of human's dignity) that have become a basement for a new type of education which must provide ability to constant cognition, co-existence, functionality and life ("Education: the necessary utopia" by UNESCO Education Commission).

In Chapter 36 of "Agenda 21" education is defined as a basement for sustainable development. In Declaration, which was adopted at World Sustainable Development Summit in 2002, it is described as an instrument for creating of humane and oriented at solving of mankind's society problems where everyone is granted his/her dignity.

According to international documents, main role of education must be shown in formation of values, behavior models and lifestyles that are necessary in providing society's sustainable development. In this sense education plays a role of initiator of society's systematical transformation on the basis of sustainable development by forming its own process of projecting given vectors in human's consciousness and realization in practice. Accordingly, except knowledge and technology, education for sustainable development is primarily turned towards values and motivation, formation of social support, thought development that are necessary for creating sustainable development society [Aichi-Nagoya Declaration on Education for Sustainable Development, 2014]. Describing universal character of ideas of sustainable development that are depicted in international documents, education was named as an "Education for Sustainable Development" or "Education in the interest of Sustainable Development" (ESD). Given model of educational activity forms basics of global transformation of this sphere in order to provide needs of society's transformation on the sustainable development basis. In Europe its contours were formed after World Forum in Johannesburg an UN General Assembly at $5^{\text {th }}$ Conference "Environment for Europe", when Ministers of Environment of UN European Economic Commission adopted the Statement about education for sustainable development. As a concept, education for sustainable development was described as a value and practice oriented educational activity which results in interdisciplinary knowledge and systematical habits, which are based on integration of approaches to society's development, economic and environment. According to this, "sustainable development must be integrated into all educational programs and, firstly, ecology programs of all levels, including professional training and 
constant education" [Education for Sustainable Development Goals: Learning Objectives, 2017].

Modern international documents and scholars of sustainable development describe education not only as a part of sustainable development society, but also as a basic of its formation, one of the most important mechanisms of its creation. Global actions program of education for sustainable development accents necessity of simultaneous implementation of two most important integrational processes: integration of basics and values on sustainable development concept into educational system and constitution of education as a part and mechanism of creation of sustainable development society [Global Action Programme 2015-2019].

Innovation has defined several specifics of education of sustainable development that are already well generalized in modern researches. In contextual view it combines ecologic, economic, and social problems "concentrating on security, and values formation". In methodical view it is dialogical, interactive, transverse skills formation oriented. In purposeful view it has advanced character, practical orientation, and integrates formal, non-formal and informal education in context of sole understanding of necessity if education, education and enlightenment [Koreneva, 2018:113].

As a result, education for sustainable development shows all the necessary from sustainable development concept in unity of ecologic, social-cultural, and economic spheres. Orienteers are not only solving of global ecological problems, but also formation of fair and dignified society, creation of prerequisites for intellectual development of everyone in conditions of ethically-free development, ethical maturity, cultural diversity, conserving of cultural-value succession of generations.

In general, education for sustainable development presents by itself innovative model of education that transforms all sphere of educational activity on basis of sustainable development - organization of educational process; social enlightenment and education; formation of value and worldview system based on sustainable development's principles; implementation of dialogical education instead of monologue translation of knowledge; maximization of practical part and social involvement of educational process [Melmann, 2015:26]. Among most important task of education for sustainable development that were formed in "Agenda 21", we should pay attention on creation of innovative educational system that are absolutely oriented towards values and targets of formation of sustainable development society; providing of healthy lifestyle, civil and personal activity of every person; formation of a new system of values [Agenda 21, 1992]. In "Strategies for Education for Sustainable Development" UN European Economic Commission it is stated, that education for sustainable development must be considered as a process which covers all elements of life sphere.

Model of education for sustainable development is quite structured and contextually difficult. It includes several spheres; each of them can be a basement of conceptual understanding of given model in different interpretations. In worldview and values sphere sustainable development is interpreted as a regular step of society's development with coming out towards its systematical characteristics in noospheric concept. Technological sphere accents on using of modern technologies for emptying society from ecological development factors. Ecological sphere describes necessity of strict adaptation of social and economic development based on imperatives of co-evolutional 
development and needs in solving of global economic problems. The social sphere accents on the sustainable development as the humanization of society using the justification of the "new humanism in the context of a combination of environmental and humanistic factors". The economic sphere allows realizing innovative transformation of economy towards ecological purposes, mechanisms, values. Sociocultural sphere concentrates on the tasks of ecological culture within global changes systems and the culture of modern development. Administrative and political sphere shows patterns of the new world order, warning and regulation of threats and risks that appear in the process of establishing of sustainable development society [Multimodus principles of postgraduate education for sustainable development, 2018:23].

On the basis of the carried-out analysis as a whole it is expedient to define the following directions of development of the education that functions for the purpose of realization of bases of sustainable development.

First, it is an educational mission to develop knowledge about a society of sustainable development. This task is solved not only by the educational tools, but also by the mass media, the implementation of public and state enlightenment projects, the activities of various actors in the networks of social intelligence, online communities and more.

Secondly, the formation of values of sustainable development. This is mainly the task of social institutions, including education. At the same time, a new system of values is being formed both at the individual and general social levels, within which the transition from a traditional society with its ideology of boundless development and technological innovations to a new society with noosphere and co-evolutionary orientations should be ensured.

Third, we are talking about the formation of a system of social institutions that ensure the formation of sustainable development. One of such institutions is education for sustainable development, which acquires an institutional character as it penetrates into education of issues, values and forms of communication, typical for a society of sustainable development.

\section{Development}

Accordingly, we can talk about the institutionalization of education for sustainable development in the form of certain subjects and disciplines, projects, as well as systemic changes in education itself on the principles of sustainable development. In general, the content of education for sustainable development in the form of a combination of environmental, economic and social dimensions has been clearly distinguished to date. Although a fundamentally new filling of the value system due to ecology and nature conservation is being introduced, it is not a nihilistic rejection of traditional values, but a combination of ecosystem ideas and traditional ideas of humanism and views on society in the interests of each member.

Although international standards and national educational programs provide for a combination of humanistic and environmental values in the practical educational process, in particular, in Ukraine, this is not always done at a high enough level. Accordingly, the analysis of the educational process within the criteria of sustainable development often demonstrates not just the dominance of environmental issues but in 
fact the reduction of all education for sustainable development to environmental education. "In Ukraine, education for sustainable development is developing on the basis of environmental education. Therefore, $\ldots$ in Ukraine pays much attention to environmental education, which is the most important component of the SRF, its subject and conceptual basis" [Popova, 2015: 197]. At the same time, education for sustainable development is much more diverse than environmental education - in terms of content, values and forms of implementation it is much wider than the actual environmental education. Here are two main differences. It forms model ideas about educational innovations, forms their worldview and methodological guidelines, is an integrative basis of the educational system (rather than the educational sector, as in case with environmental education).

The reduction of education for sustainable development to the issue of environmental education poses a threat to the values associated with the humanistic interpretation of education, as well as the prospects for the formation of humanistic values based on social relations in a society of sustainable development. At the same time, today the ecological component of education for sustainable development dominates not only in the form of subjects, projects, areas of innovation. In the form of dominant values, it determines the directions of implementation of the principles of sustainable development in the educational process, formed on the basis of environmental ethics and environmental education [Training teachers to teach sustainable development, 2015:19].

To analyse this problem on the basis of the Dnipro Academy of Continuing Education, a project was implemented to study the values and priorities of teachers who teach subjects at school, focused on the implementation of the principles of sustainable development. The subject of the study is determined by the importance of the value component of education for sustainable development, which is emphasized in the UNECE Development Strategy. Researchers of the problem also note that "changes in values and priorities are seen as a key task of psychological and philosophical support of education for sustainable development" [Shmeleva, 2009:47].

In total, during 2019-2020, a survey of 280 teachers involved in the process of introducing components of education for sustainable development in the educational system of Dnipropetrovsk region was conducted on understanding the values and mechanisms for implementing education for sustainable development. Most attention was paid to teachers of the specialized course "Lessons for Sustainable Development". Some of the interviewed teachers implement the principles of education for sustainable development within such disciplines as "Science", "Fundamentals of life safety", "I explore the world", "I am in the world", "Fundamentals of health", "Biology and ecology".

The hypothesis was based on understanding the value context in which teachers implement the guidelines of education for sustainable development, their personal values and preferences as a factor in selecting material for the implementation of the content of education for sustainable development in teaching certain disciplines. The task was set to study the values of teachers, which aims to establish the relevance of the values that are transmitted in the process of teaching education for sustainable development, its general orientation. The results of the study were to make it possible to identify problems in the 
teaching of these subjects based on their understanding by teachers themselves. After all, it is well known that a teacher can give students only what he/she has. Accordingly, in any course, he/she transmits to students what he/she is convinced of, based on their own system of values and understanding of the subject.

The study was conducted in September 2019 - April 2020 by direct questioning and processing of data obtained by employees of the Department of Education and Culture of Health, the Department of Psychology and the Department of Education Quality Monitoring. At the heart of the study were three problems.

First, determining the relationship between the role of components of sustainable development in the educational process (environmental, economic and social components). The task was to determine the place of these components among the value priorities of teachers and, accordingly, to what extent and quality these value priorities are transmitted in the educational process in the teaching of subjects, focused on the translation of the principles of sustainable development.

Secondly, determining the interaction of environmental and humanistic values among the value orientations of teachers in terms of the presence of their synthesis on the priority.

Third, the establishment of possible mechanisms for optimizing the value system of teachers, primarily in terms of forming those forms of intelligence that promote the integration of environmental, social and economic components of education for sustainable development.

In the first case, the attitude of teachers to those elements of education for sustainable development that reflect its environmental, social and economic components were analysed. At the same time, the dominance of ecological values should be stated without a doubt. Thus, when choosing the basic basis of education for sustainable development, almost $95 \%$ of teachers called the main component of the environmental world. About four percent of teachers consider economic issues to be the basis of education for sustainable development, and about one percent of surveyed teachers consider social issues to be the most important component of education for sustainable development.

Table 1. Which component of the concept of sustainable development plays the most important role? (one answer)

\begin{tabular}{|l|l|l|}
\hline № & $\begin{array}{l}\text { The name of the component of the concept of } \\
\text { sustainable development }\end{array}$ & $\%$ selection \\
\hline 1 & Ecologic & $94,7 \%$ \\
\hline 2 & Economic & $4,2 \%$ \\
\hline 3 & Social & $1,1 \%$ \\
\hline
\end{tabular}

In particular, teachers believe that the integration of the content of education for sustainable development is based on environmental values, they are subject to social and economic issues. Assessing the importance of certain innovation processes for the formation of a society of sustainable development, most educators preferred as the main trend of its development the implementation of the principles of nature conservation and reducing human impact on nature. Economic aspects of the formation of a society of sustainable development are considered almost exclusively in line with the introduction of environmental technologies for resource conservation, nature protection, biodiversity and more. With regard to the social dimension, the issue of forming new 
relationships between people, and a new system of values outside of environmental issues at the national level, is not considered at all. A society of sustainable development is considered as a society that is fully focused on the task of nature conservation. The specifics of the reflection of this process in the system of social relations are not taken into account.

Table 2. Determine on a 10-point scale the importance of major innovation processes for the formation of a society of sustainable development (1 - the lowest, 10 - the highest):

\begin{tabular}{|l|l|l|}
\hline № & Name of the innovation process & Average score \\
\hline 1. & Environmental activities & 9,2 \\
\hline 2. & Waste management & 8,9 \\
\hline 3. & Ensuring biodiversity & 8,8 \\
\hline 4. & Formation of resource-saving technologies & 8,6 \\
\hline 5. & Formation of innovative economy & 6,4 \\
\hline 6. & Development of information technologies & 5,8 \\
\hline 7. & Formation of a justified international order & 5,1 \\
\hline 8. & Intercultural integration & 3,6 \\
\hline 9. & Focus on human development & 3.5 \\
\hline 10. & Humanization of human relations & 2,7 \\
\hline 11. & Humanistic transformation of media culture & 2,4 \\
\hline 12. & Changes in family and domestic relations & 1,6 \\
\hline
\end{tabular}

Communication during the learning process demonstrated the negative consequences of such a hierarchy of values. When discussing the problems of sustainable development, teachers cannot explain how the transformation of the main social spheres of culture, communication system, life, family, etc. on the basis of sustainable development takes place. In fact, the whole layer of society's culture is simplified to the issues of nature protection and environmental ethics.

In this regard, the dominance in the views of teachers on the factors of formation of a society of sustainable development of formal and organizational priorities in comparison with personal and value values is quite significant.

Table 3. What plays a crucial role in the formation of a society of sustainable development? (one answer)

\begin{tabular}{|l|l|l|}
\hline № & Factor of formation of a society of sustainable development & $\%$ selection \\
\hline 1. & $\begin{array}{l}\text { Establishment of international institutions to ensure sustainable } \\
\text { development }\end{array}$ & $36 \%$ \\
\hline 2. & Changes in development strategy at the national level & $27 \%$ \\
\hline 3. & $\begin{array}{l}\text { Formation of an environmentally friendly management and legal } \\
\text { system }\end{array}$ & $21 \%$ \\
\hline 4. & $\begin{array}{l}\text { Formation of a new system of values at the social and personal } \\
\text { levels }\end{array}$ & $8 \%$ \\
\hline 5. & $\begin{array}{l}\text { Activity of each person, formation of innovative and socially } \\
\text { active person }\end{array}$ & $6 \%$ \\
\hline 6. & \begin{tabular}{l} 
Formation of new relations between people, nations, cultures \\
\hline
\end{tabular} & $2 \%$ \\
\hline
\end{tabular}

The vast majority of teachers believe that the main role in the process of its formation should be played by state and interstate institutions, legal and administrative systems. At 
the same time, the value components of this process, changes in culture and the activity and initiative of individuals remain unnoticed. This, without any doubt, is reflected in the educational process, preventing the formation of activist values, initiative and innovation of the younger generation as the creator of new social realities.

The correlation of humanistic and ecological values among the preferences of teachers turned out to be quite unexpected. The vast majority of educators agree that environmental values should be at the heart of an educational process focused on the values of sustainable development.

Table 4. What value system is most important for the formation of a sustainable development society (one answer):

\begin{tabular}{|l|l|l|}
\hline № & System of values & $\%$ selection \\
\hline 1. & Environmental ethics & $36 \%$ \\
\hline 2. & The system of universal values & $31 \%$ \\
\hline 3. & Noosphere values & $21 \%$ \\
\hline 4. & Christian ethics & $7 \%$ \\
\hline 5. & Humanistic values & $5 \%$ \\
\hline
\end{tabular}

However, the ways of integrating environmental and traditional humanistic values remain unclear to them. Accordingly, there is in fact not a process of synthesis of ecological values on the basis of humanism, but in fact the displacement of humanistic values by ecological ones. When answering specific questions, the vast majority of educators show a tendency to subordinate humanistic values to environmental ones.

Thus, more than a third of the surveyed teachers consider it appropriate to reduce the number of people on the planet as a mechanism to reduce the anthropogenic load on nature. More than a third of teachers surveyed believe that reducing resource consumption is unalterable, regardless of how it will affect the quality of life of specific people. Approximately the same number of teachers considers the task of educating a caring attitude to nature, the environment more important than the task of forming constructive communication, mutual understanding, and empathy between people. Most respondents have a positive attitude to such processes as deurbanization, reduction of human habitat, birth control, radicalization of criminal liability for violations of environmental legislation. However, such radical measures as restriction of rights and freedoms, lowering of social and medical standards, forced sterilization do not find significant support.

Table 5. What tendencies of reduction of anthropogenic load on nature should be applied, are possible to apply under certain conditions, or are impossible to apply in any case:

\begin{tabular}{|l|l|l|l|l|}
\hline № & Tendency & necessary & probably & impossible \\
\hline 1. & Implementat a population reduction strategy & $68 \%$ & $26 \%$ & $16 \%$ \\
\hline 2. & $\begin{array}{l}\text { Reduction of areas of residence of people with } \\
\text { accommodation on the site of settlements of } \\
\text { protected areas }\end{array}$ & $52 \%$ & $34 \%$ & $14 \%$ \\
\hline 3. & $\begin{array}{l}\text { Introduce severe criminal liability for environmental } \\
\text { damage, including life imprisonment }\end{array}$ & $48 \%$ & $41 \%$ & $11 \%$ \\
\hline 4. & Deurbanization, revival of rural settlement & $42 \%$ & $39 \%$ & $19 \%$ \\
\hline 5. & $\begin{array}{l}\text { Reducing resource consumption with declining } \\
\text { quality of life }\end{array}$ & $37 \%$ & $46 \%$ & $17 \%$ \\
\hline
\end{tabular}




\begin{tabular}{|l|l|l|l|l|}
\hline 6. & $\begin{array}{l}\text { Replacement of the humanocentric system of } \\
\text { values by ecocentric }\end{array}$ & $35 \%$ & $32 \%$ & $33 \%$ \\
\hline 7. & $\begin{array}{l}\text { Birth control and promotion of small families and } \\
\text { childlessness }\end{array}$ & $33 \%$ & $52 \%$ & $12 \%$ \\
\hline 8. & $\begin{array}{l}\text { Restrictions on human rights and freedoms to } \\
\text { reduce consumption, and control pollution }\end{array}$ & $17 \%$ & $32 \%$ & $51 \%$ \\
\hline 9. & $\begin{array}{l}\text { Decrease in social standards, standards of medical } \\
\text { care, and pension provision }\end{array}$ & $72 \%$ & $34 \%$ & $54 \%$ \\
\hline 10. & Forced sterilization of the population & $7 \%$ & $82 \%$ \\
\hline
\end{tabular}

There is a widespread perception among educators that there is a tendency in modern art and popular culture to accuse humanity of leading the planet to destruction and to be punished accordingly. For example, when discussing the issue of justifying of humanity's punishment (with a demonstration of excerpts from When the Planet Stopped), about eighty percent rate the idea of punishing humanity for harming the planet as fair. When discussing extremist slogans and posters of quasi-environmental content (for example, "Save the forest - cut down people"), almost a quarter of teachers did not condemn them.

Table 6. With which statement about the responsibility of mankind for the crisis of the environment do you agree, partially agree or disagree:

\begin{tabular}{|l|l|l|l|l|}
\hline № & The content of responsibility & agree & partly agree & disagree \\
\hline 1. & $\begin{array}{l}\text { Mankind is responsible for the crisis of the } \\
\text { environment and rightly deserves this } \\
\text { punishment }\end{array}$ & $56 \%$ & $23 \%$ & $21 \%$ \\
\hline 2. & $\begin{array}{l}\text { The life of humanity and civilization is less } \\
\text { important than life on the planet }\end{array}$ & $32 \%$ & $36 \%$ & $32 \%$ \\
\hline 3. & $\begin{array}{l}\text { Human interests can be sacrificed for the } \\
\text { safety of life on Earth }\end{array}$ & $19 \%$ & $43 \%$ & $38 \%$ \\
\hline 4. & $\begin{array}{l}\text { The life of humanity and civilization is } \\
\text { more important than life on the planet }\end{array}$ & $14 \%$ & $47 \%$ & $39 \%$ \\
\hline 5. & $\begin{array}{l}\text { The disappearance of human civilization } \\
\text { can be seen as a mechanism for saving life } \\
\text { on planet Earth }\end{array}$ & $7 \%$ & $19 \%$ & $74 \%$ \\
\hline
\end{tabular}

In other words, the idea of punishing humanity is quite common among teachers who teach subjects within the strategy of introducing education for sustainable development, although there is no absolute support for this idea among them. However, the presence of such views is quite threatening in terms of areas of education of the younger generation, as in one form or another it is broadcasted in the student environment. Thus, the general principle is realized as "education is a fundamental element of sustainable development, providing individuals with the opportunity to realize their own ideas about society,... to promote the education of a new way of thinking in the individual" [Popova, 2015:193].

Our study confirms the conclusions of experts that "in the practically implemented models of education for sustainable development conceptual and thematic scholasticism and inconsistency of their developers is often dominated by, which often discredits the very idea of such education" [Nepeina, 2009:22]. In our opinion, we note the insufficient 
level of ideological and methodological support of the process of formation of education for sustainable development, which is not realized by its subjects. The model is implemented in schools without adequate development of general issues of translation of the principles of sustainable development in the educational process in general and their reflection in specific disciplines, as well as in the process of training relevant teachers. In fact, education today works "on the problems of environmental education on the way to education for sustainable development" [Stepanov, 2010:94].

One of the possible ways to solve these problems can be considered the formation of new, more adapted to the needs of sustainable development of value-cognitive characteristics of teachers. In particular, in the course of the research a certain regularity was revealed between the level of adequate correlation of social-humanistic values and ecological values in teachers with a higher level of development of social intelligence. The survey showed that professionals with a higher level of social intelligence tend to more organically combine ecosystem and social and humanitarian values. Moreover, it is among this group of teachers that the formation of counteraction to extreme manifestations of ecosystem values, which have an inhumane character, is taking place.

Table 7. Percentage of those who disagree with the statement about the responsibility of mankind for the crisis of the environment, depending on the level of development of social intelligence:

\begin{tabular}{|l|l|l|l|l|}
\hline № & The content of responsibility & High & Medium & Low \\
\hline 1. & $\begin{array}{l}\text { Mankind is responsible for the crisis of the } \\
\text { environment and rightly deserves this } \\
\text { punishment }\end{array}$ & $37 \%$ & $32 \%$ & $6 \%$ \\
\hline 2. & $\begin{array}{l}\text { The life of humanity and civilization is less } \\
\text { important than life on the planet }\end{array}$ & $58 \%$ & $26 \%$ & $11 \%$ \\
\hline 3. & $\begin{array}{l}\text { Human interests can be sacrificed for the } \\
\text { safety of life on Earth }\end{array}$ & $79 \%$ & $32 \%$ & $23 \%$ \\
\hline 4. & $\begin{array}{l}\text { The life of humanity and civilization is less } \\
\text { important than life on the planet }\end{array}$ & $62 \%$ & $64 \%$ & $31 \%$ \\
\hline 5. & $\begin{array}{l}\text { The disappearance of human civilization } \\
\text { can be seen as a mechanism for saving life } \\
\text { on planet Earth }\end{array}$ & $84 \%$ & & $19 \%$ \\
\hline
\end{tabular}

It is obvious that the sociocentric orientation, which is provided by a high level of social intelligence, provides teachers with a solid intellectual and cultural foundation for combining different values in the process of implementing the imperatives of education for sustainable development. It should be noted that researchers generally note the prospects of using the tools of socio-cultural, intercultural communication to ensure the necessary potential of education for sustainable development [Samoshkina, 2019:319].

\section{Conclusion}

In general, the results of the study indicate significant problems in the implementation of the tasks set before education for sustainable development. These problems mainly focus on the following. 
Firstly, it is the absolutization of environmental values and the lack of effective synthesis of these values with social values, and economic values partly. At the same time, there is a tendency of a certain part of teachers to accept the principles of environmental ethics as a completely self-sufficient value basis for teaching disciplines on the basis of sustainable development in educational institutions.

Secondly, there is a lack of needs and values of teachers and value-methodological principles of integration of environmental and humanistic values. At the same time, the former essentially replace the latter and the formation of humanism does not take place, which includes the issue of combining the interests of human development and the preservation of the environment. In the most radical forms this leads to problems with the combination of values of sustainable development and human values, human development.

Thirdly, to a large extent on the periphery of education for sustainable development are the problems of transformation of society itself, social relations, culture, ways of communication, interaction of people with each other, as well as the emotional component of such interaction. In other words, the values and principles of sustainable development do not address the problem of forming regulations and transforming society on the basis of these principles. Accordingly, environmental values in the form of the principles of environmental ethics, bioethics, etc. remain detached from the practice of forming social innovations and the actual formation of a society of sustainable development.

It should be noted that similar problems are recorded by other researchers. Thus, scientists from the University of Ljubljana in 2019 conducted an empirical study of the value advantages of student-teachers who are prepared to teach on the basis of sustainable development (Slovenes and Austrians). The thematic sphere of education for sustainable development is seen by Slovenian students-teachers by $38 \%$ - in the field of nature protection, $37 \%$ - in the field of ecology, and only $2 \%$ - in the humanities. Similar figures for Austrian student teachers - 37\%, 23\% and 4\%, respectively. At the same time, $55 \%$ of Slovenian students-teachers associate sustainable development with environmental issues, $15 \%$ with social issues and 13\% with economic issues. Similar figures for Austrian student teachers are as follows: 55\%, 12\%, and 13\% [Bezeljak, Torkar, Scheuch, 2019].

Meanwhile, limiting the concept of sustainable development only to the interaction of man with nature is clearly a reduction of the concept, which seriously discredits the idea itself. There are fundamental researches and innovation of scientists, which fully characterize the dimensions of sustainable development [Lepeley, 2019]. Moreover, there is a whole line of research on sustainable development within the framework of humanocentric orientation ["Innovation in human centered sustainability"].

Thus, education for sustainable development, in addition to the globalization and environmental prospects of society, includes human potential, the direction of humanization of social relations, social capital, cultural and civilizational innovations of a global nature, and ethical dimensions of civilizational change. The new educational model should include a range of problems for the development of various social systems and subsystems, primarily socio-humanitarian, economic, political, managerial, and so on. 
Of course, there are many possible readings of education for sustainable development in the context of understanding sustainable development itself, and today there are more than fifty definitions, reflecting both the complexity of the concept itself and the differences in understanding among scholars. However, in general, sustainable development is a solution not just of the problems of man and nature, but of man himself. And education for sustainable development in any case should go beyond ecocentric goals and values and focus on a comprehensively balanced development and combination of anthropocentric and biosphere-centric values. This is the model of education offered at the level of methodology and technology by specialists [Bamber, 2019].

The new model of education for sustainable development should reflect its main idea, the creation of preconditions for the implementation as a basic model of selforganization of society of real humanism [Rizhak, 2011: 79], on the basis of which the social life of mankind as a whole and of each country in particular should be arranged. In this case, the criteria of quality of human life, including the state of the environment, should be the main in determining the goals, directions, mechanisms of creating a society for sustainable development. The new model of education should provide a focus on people as the main object of sustainable development, subordinating value changes to the task of socialization and humanization of social development, taking into account environmental constraints. This, by the way, is what the Strategy for Balanced Development Education, developed under the auspices of the United Nations Economic Commission for Europe (UNECE), is all about.

Possible solutions to problems, which logically follow from the results of our study, focus on enriching the value-cognitive content of education for sustainable development through the expansion of the social and humanistic component. There are quite serious studies in this area, which consider sustainable development in terms of socialization of the individual, value education, interactivity [Poeck, Östman L., Öhman J., 2019]. In our opinion, specialized modules are needed in the educational process, which are devoted to the implementation of the principles of sustainable development in the social sphere and the essence of innovative forms of humanism, combining traditional humanistic and environmental values.

Improving of the professional skills of teachers themselves, who teach subjects on the basis of sustainable development should be considered an important area. First of all, we are talking about the development of those types of intelligence that help maximize the humanistic and social component of the value priorities of teachers [Romanenko, Bratanich, Kutsiy, 2020:38]. Based on the results of the study, it is necessary to pay attention to the development of social intelligence. However, it can be hypothesized that the development of such forms as emotional intelligence, communicative intelligence and practical intelligence will also be positive. Today, there are many effective methods of developing such forms of intelligence, which should be used to improve the professional skills of teachers as subjects of education for sustainable development.

Radical changes in educational policy must be made to work effectively with teachers. At the national and regional levels, the development of education for sustainable development should be approved as the main mechanism for the formation of an innovative type of thinking, focused on the subordination of all processes to the task of 
ensuring sustainable development. This should be reflected not in declarations, but in specific programs, projects, strategies, in particular, and in specialized programs for inservice training of teachers and training of teachers to teach disciplines focused on sustainable development (for example, as a second teacher education). In general, systemic education reform on the basis of sustainability should include such areas as "reorientation of functional and subject areas of education: design of competencies, implementation of transformative pedagogy, support of educational agents, creation of sustainable learning environments, improvement of coordination and integration, updating educational reforms" [Khmelevskaya, 2018:29].

For more adequate training of professionals in the field of education for sustainable development, it is advisable to expand cooperation with governmental and nongovernmental organizations, programs and foundations that have similar experience and potential for organizational, intellectual and resource assistance. Today, such cooperation is organized with many actors, such as: the European Union, UNESCO, the European Education Foundation, the US News Agency, the Council of Europe, the British Council, the French Cultural Center, "Tempus", IREX, the Peace Corps, the German Academic Exchange Service, the Canadian International Development Agency, "School Exchanges" and many more. However, systematic cooperation is carried out only with such organizations as the United Nations Development Program (UNDP), the United States Agency for International Development, the British Council [Sustainable Development Goals: Ukraine, 2017]. It is also necessary to intensify the activities of UNESCO departments and associated schools, of which there are several dozen in Ukraine, but the tangible result of their activities to train specialists and scientific and methodological materials in the field of education for sustainable development is very small.

In our opinion, in order to more effectively solve the practical problems of improving the process of integrating education into the process of becoming a sustainable development society, the question of separating education for sustainable development as an independent socio-cultural and educational institution is up to discussion. This is prompted by an analysis of the complexity and diversity of the 2030 Sustainable Development Goals. Such an analysis clearly indicates a radical expansion of the subjectivity and objectivity of education for sustainable development as a social institution, the integration of innovative processes in education around the idea and principles of sustainable development. Standardization and organizational design of the institutional framework of education for sustainable development will allow much more effective measures to reorient the educational process to create new values and social relations at the national and regional levels. For the effectiveness of this work it is necessary to use the experience of institutional activities carried out in different countries and recommended for implementation in international instruments.

\section{References}

Agenda 21. (Adopted by the United Nations Conference on Environment and Development, Rio de Janeiro, 3-14 June - 1992). Available at: https://sustainabledevelopment.un.org/content/documents/Agenda21.pdf [Accessed: 17 June, 2020.]. 
Aichi-Nagoya Declaration on Education for Sustainable Development, adopted in Aichi-Nagoya, Japan, from 10 to 12 November 2014 // Database «SUSTAINABLE DEVELOPMENT KNOWLEDGE PLATFORM» / UN. - Available at: https://sustainabledevelopment.un.org/content/documents/5859AichiNagoya_Declaration_EN.pdf [Accessed: 10 May, 2019.] Available at: http://www.jstor.org/stable/pdfplus/1501686.pdf [Accessed: 20, 2008].

Bamber Ph. (2019) Teacher Education for Sustainable Development and Global Citizenship : Critical Perspectives on Values, Curriculum and Assessment.Publisher: Milton : Routledge, 2019.

Bezeljak P., Torkar G., Scheuch M. (2019). Understanding of sustainability and education for sustainable development among pre-service biology teachers. Proceedings of International Conference on Education Research (2019: Vienna), pp. 49-61. https://www.worldcat.org/title/understanding-ofsustainability-and-education-for-sustainable-development-among-pre-service-biologyteachers/oclc/1117727336\&referer=brief_results

Education for Sustainable Development Goals: Learning Objectives / UNESCO Education Sector. 2017. Available at: http://unesdoc.unesco.org/images/0024/ 002474/247444e.pdf [Accessed: 4 May, 2019.]

Global Action Programme (GAP) on Education for Sustainable Development (ESD): Goals and Objectives / UNESCO/ - Available at: https://en.unesco.org/gap/goals- and-objectives?language=en. [Accessed: 17 May, 2019.]

Khmelevskaya, O.M. (2018) Education for sustainable development: content and institutions. Demography and the social economy. (1). pp. 29-42.

Koreneva, I.M. (2018) The phenomenon of "Education for Sustainable Development": the essence and modern features of the concept. Ukrainian pedagogical journal. (2). pp. 113-123.

Lepeley María-Teresa (2019). Educonomy : unleashing wellbeing and human centered sustainable development. Information Age Publishing, Charlotte, NC.

Melmann, M. (2015). Study of the impact of the international project "Education for Sustainable Development in Action" on the participants of the educational process: an analytical report. Kyiv: Inst. Of Pedagogy Nat. acad. ped. Sciences of Ukraine.

Multimodus principles of postgraduate education for sustainable development (2018). Edited by: Ridey N.M., Sergienko V.P. Kyiv: NPU Publishing House named after M.P. Dragomanov.

Nepeina, G.V. (2009). Education for sustainable development: origins and prospects. Scientific works of the Petro Mohyla Black Sea State University of the Kyiv-Mohyla Academy complex. Ser. : Pedagogy. $(112,99)$. pp. 20-24.

Poeck K., Östman L., Ơhman J. (2019). Sustainable development teaching : ethical and political challenges Abingdon, Oxon ; New York, NY : Routledge.

Popova, I.V. (2015) International agreements on environmental education and upbringing for sustainable development. Political Science Bulletin. (78). pp. 193-202.

Rizhak, L. (2011). Philosophy of sustainable human development. Lviv: Ivan Franko Lviv National University.

Romanenko, M.I., Bratanich, B.V., Kutsiy, A.M. (2020). Social intelligence as a subject of philosophical and psychological research. Gilea. (140) pp.37-40.

Samoshkina, Ya.S. (2019). Developing the potential of intercultural competence in the education system for sustainable development. Bulletin of Tver State University. Series: Pedagogy and psychology. (1) pp. 319-326.

Shmeleva, I.A. (2009). The value paradigm of education for sustainable development. Bulletin of the Russian University of Friendship of Peoples. Series: Psychology and pedagogy. (3) pp. 47-53.

Sustainable Development Goals: Ukraine. National report. Ministry of Economic Development and Trade of Ukraine (2017). http://www.idss.org.ua/ monographs / 2017_SDGs_NationalReport.pdf [Accessed: 13 May, 2020.]

Stepanov, S.A. (2010). Education for sustainable development: methodological, substantive, organizational aspects. Bulletin of the Russian University of Friendship of Peoples. Series: Psychology and pedagogy. (2) pp. 94-98.

Training teachers to teach sustainable development. (2015). For order. O.I. Pometun. "Teachers for Democracy and Partnership", Global action plan international, Institute of Pedagogy of the National Academy of Pedagogical Sciences of Ukraine. Kyiv: Pedagogical thought. 